\title{
Inhibition of gastric secretion in man by intestinal fat infusion
}

\author{
COLIN W. O. WINDSOR, ROY COCKEL, AND MARTIN J. R. LEE
}

From Queen Elizabeth Hospital, Edgbaston, Birmingham

The rate of gastric secretion probably depends upon a balance between secretory and inhibitory stimuli; increase of the former or decrease of the latter may lead to excessive acid production (Thompson, 1962). As a possible cause of duodenal ulcer more attention has hitherto been given to increased excitatory than to impaired inhibitory mechanisms.

Inhibitory processes originating in the duodenum and small intestine have been shown in dogs. Khizhin, Lobasov, and Sokolov, quoted by Pavlov (1910), demonstrated reduced gastric secretion following the introduction of acid and fat into the duodenum. Since then many workers have confirmed these findings for acid (Sircus, 1958; Andersson, 1960; Konturek and Grossman, 1965) and fat (Lim, Ivy, and McCarthy, 1925; Menguy, 1960; Long, Brooks, and Sandweiss, 1963).

In man, although similar mechanisms are assumed to exist, few attempts have been made to define them or correlate them with duodenal ulcer disease. Ewald and Boas (1886), Roberts (1931), and Shay, GershonCohen, and Fels (1939) have demonstrated the effect on gastric secretion of fat in the duodenum in man. Shay and his colleagues (1939) suggested that the inhibitory effect was directed mainly against vagally stimulated rather than chemically stimulated juice, as intraduodenal fat prevented the acid response to insulin but not that to histamine. Card (1941) showed a lessening of the stomach's motility after fat was instilled into the duodenum, and Johnston and Duthie $(1964,1965)$ a decrease of histamine- and gastrin-induced secretion after acid in the duodenum. In the first (1964) paper, comparison of normals with duodenal ulcer patients might suggest impaired inhibition in the ulcer group. Shay and his colleagues (1942) have also suggested that the inhibition of gastric secretion and motility following duodenal acidification in duodenal ulcer patients is impaired and may be causally related to ulceration. However, Woodward and Schapiro (1958) found similar motility responses in normals and ulcer patients.

Hunt (1957) observed that acidification of stomach contents delayed gastric emptying in both groups whereas secretion was reduced in normals but increased in six of 16 duodenal ulcer patients.

We have studied the characteristics of the inhibition of gastric secretion after instilling fat into the distal duodenum and upper jejunum. The results in controls, duodenal ulcer patients, and a group with small intestinal disease are presented.

\section{MATERIALS AND METHODS}

PATIENTS Of the 30 patients studied, there were 21 successful examinations. Failure was due to the difficulties of duodenal intubation in the earlier investigations. Eight patients served as controls, their diagnoses being hiatus hernia in two, $x$-ray-negative dyspepsia in four, and the irritable colon syndrome in two. Six patients had duodenal ulcers, verified at operation. Six patients had diseases of the small intestine: three with idiopathic steatorrhoea, two regional enteritis, and one resection of the terminal ileum for ischaemia. In addition, two patients with duodenal ulcer were studied again after vagotomy and pyloroplasty as was a single patient who had only a stimulation test preoperatively.

TECHNIQUE After an overnight fast a polyvinyl tube, $2 \mathrm{~mm}$ outside diameter and $115 \mathrm{~cm}$ long, was introduced via the nose into the stomach. By means of a Seldinger stylet this was manoeuvred into the fourth part of the duodenum adjacent to the duodeno-jejunal flexure under fluoroscopic control. A double-lumen Salem sump tube was then passed into the stomach to lie in the antrum (Fig. 1).

Sampling was by continuous suction. After the resting secretion had been aspirated and discarded, 10-minute collections were made. The basal secretory rate was measured during one hour and then a gastric secretory stimulus applied using a continuous intravenous infusion of pentagastrin (Peptavlon ICI 50, 123) at a rate of $6 \mu \mathrm{g} / \mathrm{kg} / \mathrm{hr}$. This gives a maximal rate of secretion comparable to that achieved with an intravenous histamine infusion of $40 \mu \mathrm{g}$ histamine acid phosphate $/ \mathrm{kg} / \mathrm{hr}$.

After a plateau response had been reached, usually the third, fourth, and fifth 10 -minute collections, $40 \mathrm{ml}$ of a stable commercial emulsion of ground nut oil (Prosparol) at $37^{\circ} \mathrm{C}$ was infused into the small intestine via the small vinyl tube during a five-minute period. Ten-minute aspirations were continued as was the pentagastrin 


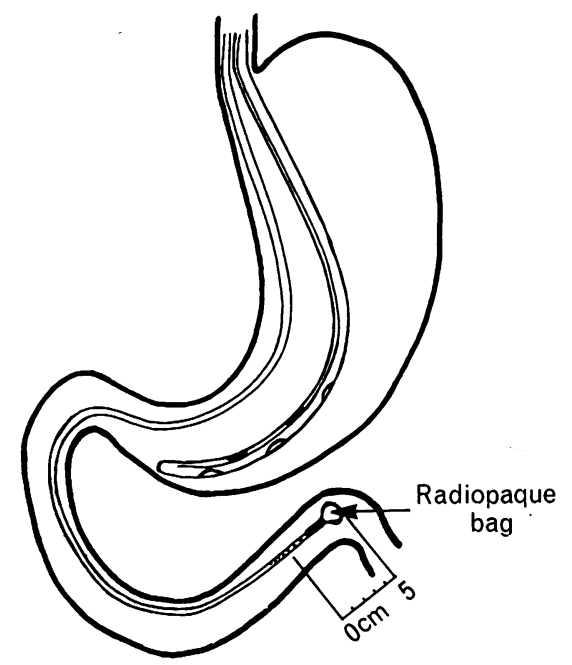

FIG. 1. Position of Salem sump tube in gastric antrum and polyvinyl tube in the fourth part of the duodenum.

stimulus until completion of the test, usually within three hours, giving up to 18 samples to evaluate.

ESTIMATIONS Acid was titrated to $p \mathrm{H} 7$ using a $p \mathrm{H}$ meter and autotitration equipment (Radiometer Corp., Copenhagen).

Pepsin was estimated by the method of Anson (1938), the results being expressed as milligrams of Armour crystalline porcine pepsin.

Sodium, potassium, and chloride determinations were made on the AutoAnalyzer (Technicon).

SAMPLING DIFFICULTIES These were mainly concerned with bile and fat emulsion reflux into the stomach after the instillation of fat. Single samples were occasionally contaminated with bile but contamination was slight and tended to be associated with the maximal volume inhibition; this would alter the titration to exaggerate the acid inhibition but decrease the volume inhibition. However, tests were discarded in which there was troublesome bile reflux. We do not consider that slight contamination of the gastric juice with bile is a significant source of error in the results of this experiment. Occasionally samples were contaminated with the fat emulsion but usually less than 1:100 dilution (estimated visually). Titrations were carried out on acid mixed with varying quantities of fat emulsion up to a 1:1 mixture; no buffering capacity could be detected. It is felt that reflux of duodenal content as described was not a significant source of error.

\section{RESULTS}

Experiments on control subjects showed that a pentagastrin plateau could be sustained for two hours by continuous infusion; there was no diminution of the response. Infusion of $40 \mathrm{ml}$ of normal saline in a similar manner to the fat emulsion showed no effect on acid output in three experiments. Only one patient complained of nausea following fat infusion, and, as this could have accounted for the inhibition noticed, he was excluded from the series.

INTERPRETATION OF RESULTS Each patient is represented in Figs. 2, 3, and 4 by a histogram. Each bar represents a 10-minute collection and shows milliequivalents of hydrogen ion per sample. The open bars represent collections after the intravenous infusion of pentagastrin and the black bars the output following the duodenal instillation of fat (given at the beginning of the first black bar). The pentagastrin infusion of $6 \mu \mathrm{g} / \mathrm{kg} / \mathrm{hr}$ was continuous throughout the experiment.

Tables I, II, III, and IV show individual data for the four groups of patients. The mean plateau response expressed as m-equiv/hr was calculated from the last three results before fat infusion, and approximates to the maximal acid output. The inhibited rate was calculated from the first four collections following fat infusion and is again expressed as milliequivalents per hour.

CONTROL GROUP (FIG. 2) Reduction of acid output seen in all patients was evident in the first 10 -minute period after fat, and persisted for at least 40 minutes in all but one patient. Three patients showed a return to stimulated levels during the time of the test. Table I shows individual data, the percentage inhibition in the 40 minutes following fat infusion varying between 14 and 92 with a mean of 59 .

DUODENAL ULCER (FIG. 3) Here the plateau was appreciably higher than in the controls. Reduction of acid secretion was again prompt in all but one instance and persisted for at least 40 minutes in all patients. One patient, no. 13 , produced no acid at all for 20 minutes.

TABLE I

\begin{tabular}{|c|c|c|c|c|c|}
\hline \multirow[b]{2}{*}{$\begin{array}{l}\text { Case } \\
\text { No. }\end{array}$} & \multirow[b]{2}{*}{$\begin{array}{l}\text { Basal } \\
\text { Rate } \\
\text { (m-equiv/ } \\
\text { hour) }\end{array}$} & & \multirow[b]{2}{*}{$\begin{array}{l}\text { Percentage } \\
\text { Inhibition }\end{array}$} \\
\hline & & $\begin{array}{l}\text { Plateau } \\
\text { Response } \\
\text { (m-equiv/ } \\
\text { hour) }\end{array}$ & $\begin{array}{l}\text { Mean Rate } \\
\text { in } 40 \text { Min } \\
\text { after Fat } \\
\text { (m-equiv/ } \\
\text { hour) }\end{array}$ & $\begin{array}{l}\text { Inhibition } \\
\text { (m-equiv) } \\
\text { hour) }\end{array}$ & \\
\hline $\begin{array}{l}1 \\
2 \\
3 \\
4 \\
5 \\
6 \\
7 \\
8\end{array}$ & $\begin{array}{l}0.4 \\
4 \cdot 1 \\
0 \cdot 5 \\
5 \cdot 3 \\
0.6 \\
3 \cdot 0 \\
1 \cdot 1 \\
6 \cdot 1\end{array}$ & $\begin{array}{l}68.4 \\
31 \cdot 2 \\
13.2 \\
27.0 \\
15.6 \\
42.4 \\
23.9 \\
31.8\end{array}$ & $\begin{array}{r}30.0 \\
6.1 \\
5.4 \\
23.0 \\
11.7 \\
36.4 \\
1.9 \\
24.6\end{array}$ & $\begin{array}{r}38.4 \\
25.1 \\
7.8 \\
4.0 \\
3.9 \\
6.0 \\
22.0 \\
7.2\end{array}$ & $\begin{array}{l}56 \\
81 \\
59 \\
15 \\
25 \\
14 \\
92 \\
23\end{array}$ \\
\hline Mean & $2 \cdot 8$ & $31 \cdot 7$ & $17 \cdot 3$ & $18 \cdot 6$ & 59 \\
\hline
\end{tabular}


The individual data (Table II) show a greater degree of inhibition than was seen in the control group. There was no evidence of defective inhibitory capacity in these cases of duodenal ulcer. Also the mean acid output after fat was similar in both normals and ulcer patients, $17 \cdot 3 \mathrm{~m}$-equiv $/ \mathrm{hr}$ and $18.7 \mathrm{~m}$-equiv $/ \mathrm{hr}$ respectively.

STEATORRHOEA (Fig. 4) Six patients with malabsorption were investigated. Two patients with idiopathic steatorrhoea in relapse had low maximal
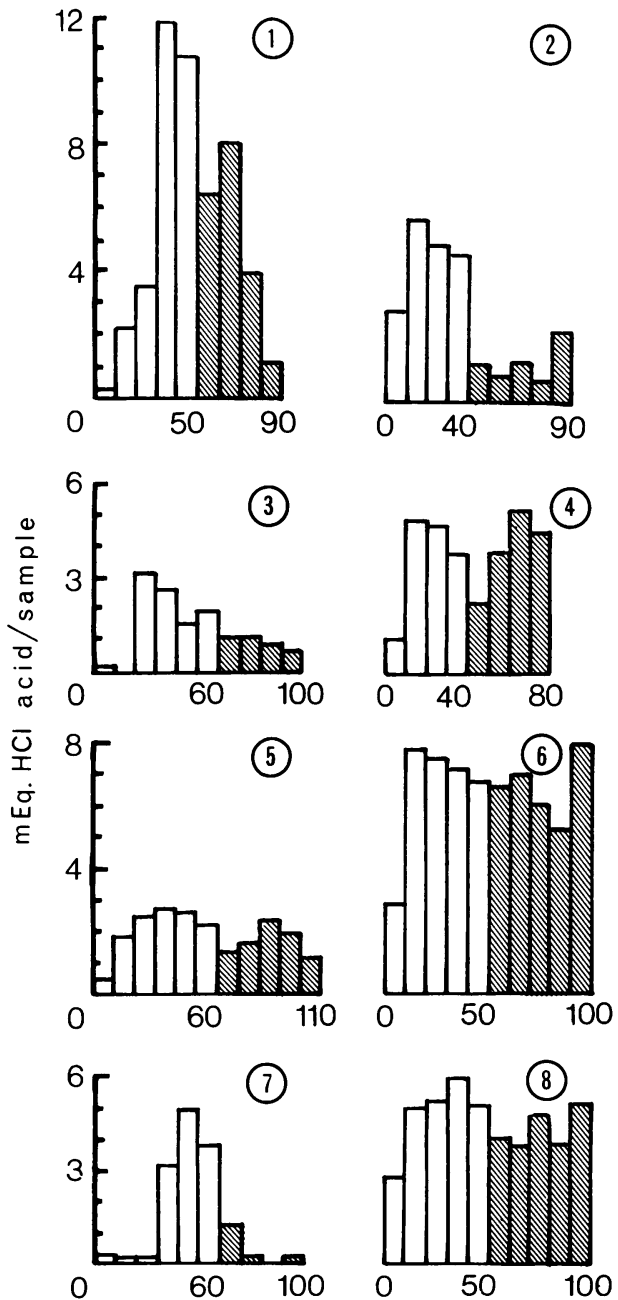

Minutes

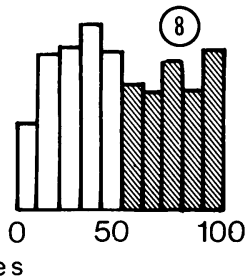

FIG. 2. Results in control group (circled figures, 1 to 8 , denote case numbers). Each bar represents m-equiv of $H C L$ per 10-minute collection. Open bars before fat infusion, black bars after fat infusion. Pentagastrin infusion $6 \mu g / k g / h r$ throughout.
TABLE II

DUODENAL ULCER PATIENTS

\begin{tabular}{|c|c|c|c|c|c|}
\hline $\begin{array}{l}\text { Case } \\
\text { No. }\end{array}$ & $\begin{array}{l}\text { Basal } \\
\text { Rate } \\
\text { (m-equiv/ } \\
\text { hour) }\end{array}$ & $\begin{array}{l}\text { Plateau } \\
\text { Response } \\
\text { (m-equiv/ } \\
\text { hour) }\end{array}$ & $\begin{array}{l}\text { Mean Rate } \\
\text { in } 40 \text { Min } \\
\text { after Fat } \\
\text { ( } m \text {-equivl } \\
\text { hour) }\end{array}$ & $\begin{array}{l}\text { Inhibition } \\
\text { (m-equiv/ } \\
\text { hour) }\end{array}$ & $\begin{array}{l}\text { Percentage } \\
\text { Inhibition }\end{array}$ \\
\hline $\begin{array}{r}9 \\
10 \\
11 \\
12 \\
13 \\
14\end{array}$ & $\begin{array}{l}3 \cdot 4 \\
9 \cdot 7 \\
4 \cdot 7 \\
4.4 \\
3.5 \\
3 \cdot 0\end{array}$ & $\begin{array}{l}44 \cdot 1 \\
63 \cdot 0 \\
57 \cdot 8 \\
49 \cdot 5 \\
64 \cdot 2 \\
66 \cdot 6\end{array}$ & $\begin{array}{l}29.6 \\
15.0 \\
17.7 \\
24.0 \\
11.9 \\
14.5\end{array}$ & $\begin{array}{l}14 \cdot 5 \\
58 \cdot 0 \\
40 \cdot 1 \\
25 \cdot 5 \\
52 \cdot 3 \\
52 \cdot 1\end{array}$ & $\begin{array}{l}33 \\
76 \\
69 \\
52 \\
81 \\
78\end{array}$ \\
\hline Mean & $4 \cdot 7$ & $57 \cdot 5$ & $18 \cdot 7$ & $40 \cdot 4$ & 70 \\
\hline
\end{tabular}
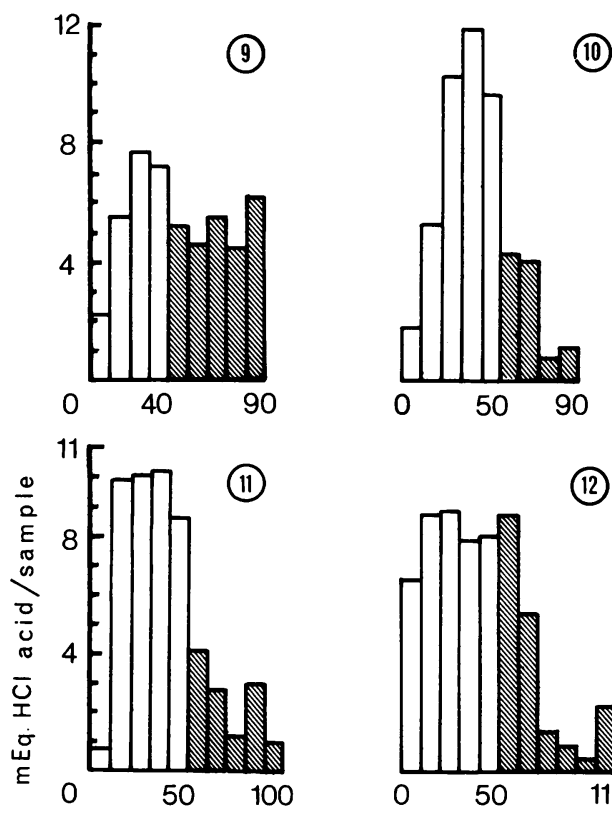

(12)
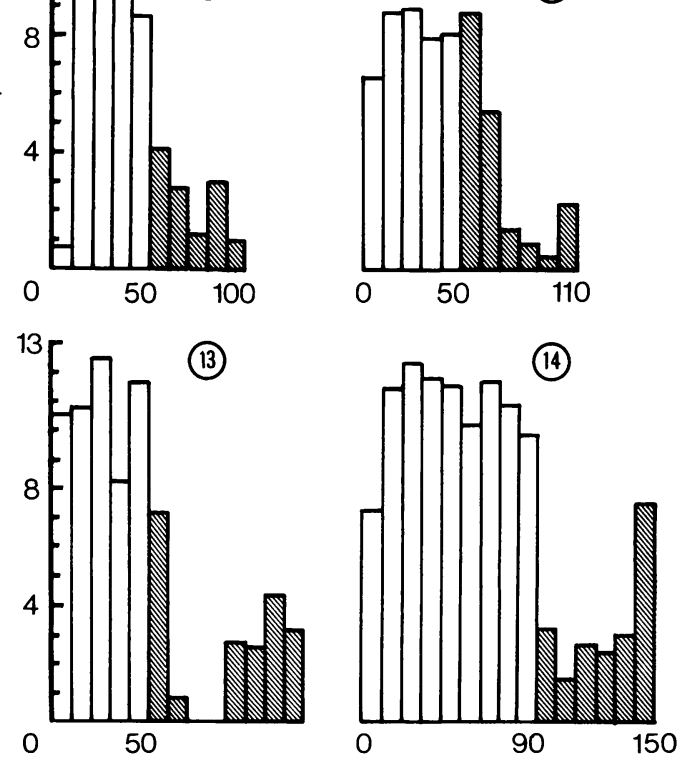

Minutes

FIG. 3. Results in duodenal ulcer group (circled figures, 9 to 14, denote case numbers). Each bar represents m-equiv of HCL per 10-minute collection. Open bars before fat infusion, black bars after fat infusion. Pentagastrin infusion $6 \mu \mathrm{g} / \mathrm{kg} / \mathrm{hr}$ throughout. 
acid outputs. One of these (no. 19) failed to inhibit acid following the instillation of fat but the other (no. 16) responded. The third patient with idiopathic steatorrhoea (no. 20), in remission with an almost normal jejunal biopsy and no steatorrhoea, showed prompt and almost complete inhibition $(98 \%)$. Of the

TABLE III

\begin{tabular}{|c|c|c|c|c|c|}
\hline \multirow[b]{2}{*}{$\begin{array}{l}\text { Case } \\
\text { No. }\end{array}$} & \multirow[b]{2}{*}{$\begin{array}{l}\text { Basal } \\
\text { Rate } \\
\text { (m-equiv/ } \\
\text { hour) }\end{array}$} & \multicolumn{3}{|c|}{ STEATORRHOEA PATIENTS } & \multirow[b]{2}{*}{$\begin{array}{l}\text { Percentage } \\
\text { Inhibition }\end{array}$} \\
\hline & & $\begin{array}{l}\text { Plateau } \\
\text { Response } \\
\text { (m-equiv/ } \\
\text { hour) }\end{array}$ & $\begin{array}{l}\text { Mean Rate } \\
\text { in } 40 \text { Min } \\
\text { after Fat } \\
\text { (m-equiv/ } \\
\text { hour) }\end{array}$ & $\begin{array}{l}\text { Inhibition } \\
\text { (m-equiv/ } \\
\text { hour) }\end{array}$ & \\
\hline $\begin{array}{l}15 \\
16 \\
17 \\
18 \\
19 \\
20\end{array}$ & $\begin{array}{l}1 \cdot 2 \\
0 \cdot 4 \\
1 \cdot 4 \\
6 \cdot 4 \\
0 \cdot 5 \\
2 \cdot 3\end{array}$ & $\begin{array}{r}35 \cdot 1 \\
4 \cdot 8 \\
24 \cdot 9 \\
42 \cdot 9 \\
8 \cdot 4 \\
35 \cdot 4\end{array}$ & $\begin{array}{r}24 \cdot 8 \\
2 \cdot 2 \\
2.9 \\
36 \cdot 3 \\
8 \cdot 4 \\
0 \cdot 6\end{array}$ & $\begin{array}{r}10 \cdot 3 \\
2 \cdot 6 \\
22 \cdot 0 \\
6 \cdot 6 \\
0 \\
34 \cdot 8\end{array}$ & $\begin{array}{r}29 \\
54 \\
88 \\
15 \\
0 \\
98\end{array}$ \\
\hline Mean & $2 \cdot 0$ & $25 \cdot 2$ & $12 \cdot 5$ & $12 \cdot 7$ & 50 \\
\hline
\end{tabular}

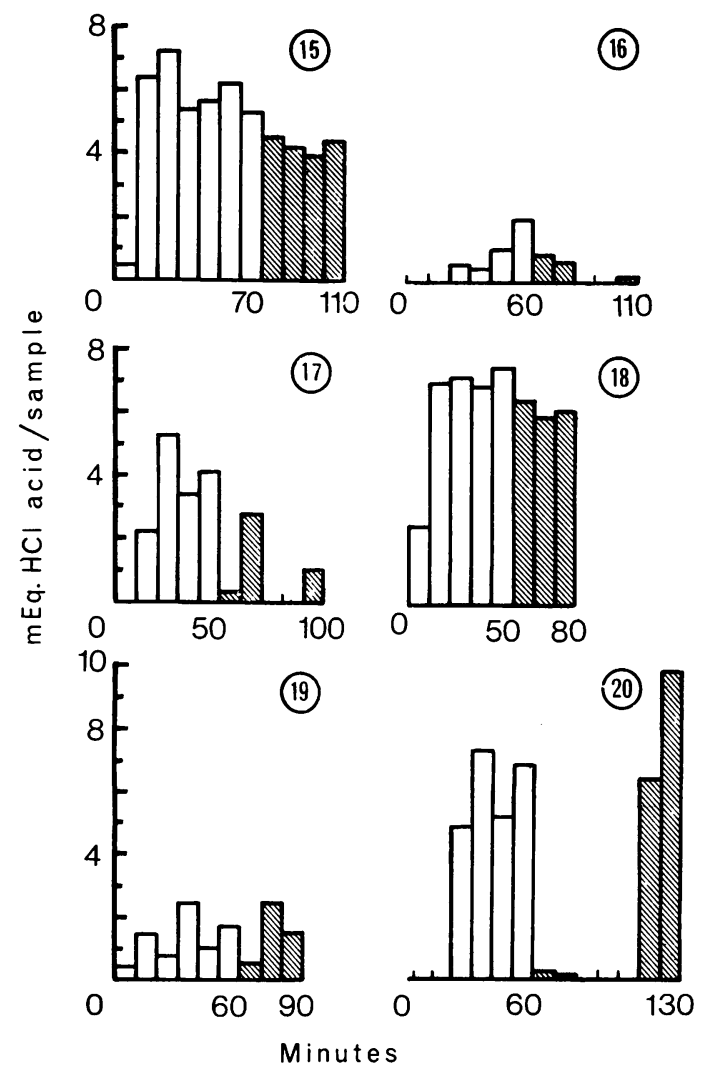

FIG. 4. Results in steatorrhea group (circled figures 15-20 denote case numbers). Each bar represents 1 m-equiv of HCL per 10-minute collection. Open bars beforefat infusion, black bars after fat infusion. Pentagastrin infusion $6 \mu \mathrm{g} / \mathrm{kg} / \mathrm{hr}$ throughout. patients with regional enteritis and steatorrhoea one (no. 17) responded as the controls while the other (no. 18) showed only a $15 \%$ reduction. The latter patient has had an extensive terminal ileal resection in addition to an ileotransverse colostomy bypassing the remaining ileum and ascending colon. His steatorrhoea was gross, and partially corrected by oral bile salts, probably an indication of cholerhoeic enteropathy (Hofmann, 1967). The remaining patient (no. 15) who had undergone resection of the terminal ileum following a mesenteric embolism, showed a response similar to those in the control group.

AFTER VAGOTOMY AND PYLOROPLASTY Two patients from the duodenal ulcer group were studied again three months postoperatively (nos. 12 and 14). Bile reflux occurred and it was felt that reduction of acid following fat infusion might be due to this. However, one patient (no. 21, Table IV), having had a routine test of acid secretion preoperatively, subsequently had a satisfactory inhibition test. His preoperative maximal acid output was reduced by $52 \%$, suggesting that he had had a complete vagotomy (Lancet, 1967). The inhibition produced by fat $(37 \%)$ corresponded with that seen in patients with intact vagi, suggesting that the pathway is not via the vagus nerve.

VOLUME AND ACID CONCENTRATION Following the fat infusion the volume of stimulated gastric secretion was reduced. The pattern was virtually the same as that of the acid inhibition already shown in the histograms (Figures 2, 3, and 4). For this reason we have not included individual data.

Acid concentration tended to remain constant in the stimulated and inhibitory periods, suggesting that there was a simple reduction of output from the parietal cells. However, in six patients there was a

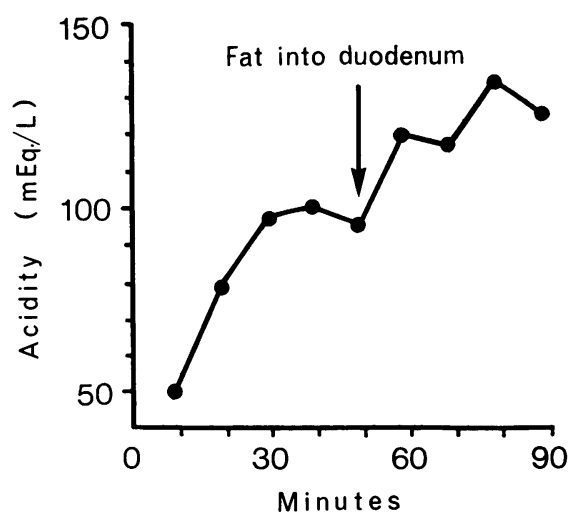

FIG. 5. Acid concentration (m-equiv/litre) in 10-minute collections. Pentagastrin infusion $6 \mu \mathrm{g} / \mathrm{kg} / \mathrm{hr}$ throughout. 
TABLE IV

AFTER VAGOTOMY AND PYLOROPLASTY

\begin{tabular}{|c|c|c|c|c|c|c|c|}
\hline \multirow[t]{2}{*}{ Case No. } & \multicolumn{2}{|c|}{ Before Vagotomy } & \multicolumn{4}{|l|}{ After Vagotomy } & \multirow[b]{2}{*}{$\begin{array}{l}\text { Percentage } \\
\text { Inhibition }\end{array}$} \\
\hline & $\begin{array}{l}\text { Basal Rate } \\
\text { (m-equiv/hour) }\end{array}$ & $\begin{array}{l}\text { Plateau Response } \\
\text { (m-equiv/hour) }\end{array}$ & $\begin{array}{l}\text { Basal Rate } \\
\text { (m-equiv/hour) }\end{array}$ & $\begin{array}{l}\text { Plateau Response } \\
\text { (m-equiv/hour) }\end{array}$ & $\begin{array}{l}\text { Mean Rate in } \\
40 \text { Min after Fat } \\
\text { (m-equiv/hour) }\end{array}$ & $\begin{array}{l}\text { Inhibition } \\
\text { (m-equiv/hour) }\end{array}$ & \\
\hline 21 & $10 \cdot 0$ & $46 \cdot 6$ & $0 \cdot 4$ & $22 \cdot 2$ & $14 \cdot 1$ & $8 \cdot 1$ & 37 \\
\hline
\end{tabular}

TABLE V

PEPSIN CONCENTRATION IN 10-MINUTE COLLECTION PERIODS

\begin{tabular}{|c|c|c|c|c|c|c|c|c|c|c|c|c|c|c|c|c|c|c|}
\hline \multirow[t]{2}{*}{ Diagnosis } & \multicolumn{5}{|c|}{ Basal Concentration } & \multicolumn{6}{|c|}{ Stimulated Concentration } & \multicolumn{7}{|c|}{ Inhibited Concentration } \\
\hline & 1 & 2 & 3 & 4 & Mean & 1 & 2 & 3 & 4 & 5 & Mean & 1 & 2 & 3 & 4 & 5 & 6 & Mean \\
\hline Duodenal ulcer & 456 & 524 & 420 & - & 466 & 410 & 430 & 440 & 390 & 370 & 408 & 324 & 376 & 358 & 290 & - & - & 337 \\
\hline Duodenal ulcer & 410 & 444 & 460 & - & 438 & 540 & 556 & 470 & 420 & 340 & 465 & 316 & 200 & 90 & 110 & 100 & 240 & 176 \\
\hline Duodenal ulcer & 450 & 520 & 454 & 470 & 473 & 212 & 452 & 452 & 336 & 244 & 339 & 224 & 212 & 330 & 360 & 324 & - & 290 \\
\hline Control & 54 & 340 & 348 & 262 & 368 & 460 & 420 & 340 & 362 & 440 & 404 & 240 & 404 & 340 & 330 & 294 & - & 321 \\
\hline Steatorrhoea & 198 & 178 & - & - & 188 & - & 316 & 356 & 286 & 304 & 315 & 150 & 160 & - & - & 160 & - & 156 \\
\hline
\end{tabular}

slight but definite rise in the acid concentration following fat infusion, despite the decrease in volume of juice. Figure 5 shows the relevant data from case 2 of the control group; there was a rise in concentration from $95 \mathrm{~m}$-equiv/litre to $125 \mathrm{~m}$-equiv/litre.

PEPSIN Table V shows results of pepsin determinations in five patients, three with duodenal ulcer, one control ( $x$-ray-negative dyspepsia), and one with steatorrhoea. Immediately pepsin concentration and secretion rate were reduced in the 10 minutes following fat infusion. This response was sustained throughout the test. All patients behaved in a similar manner.

ELECTROLYTES Studies were carried out in five patients. Sodium, potassium, and chloride concentrations were estimated on all samples. These results are not detailed as no consistent trends emerged.

There was a slight but not significant fall in the potassium ion concentration during the phase of inhibition.

\section{DISCUSSION}

Our results show that there is a mechanism inhibiting gastric acid production in man in response to the instillation of small quantities of fat into the duodenum and small intestine. The effect is powerful since it depresses by approximately $50 \%$ a near maximal acid output, and would seem to be at parietal cell level causing a block to a gastrin receptor. The alternative mode of action, that of binding the gastrin analogue molecules in the circulation, has no physiological precedent and is less likely. These results are similar to those of Bibler, Harkins, and Nyhus (1965) in the dog.
The rapid onset of the phenomenon, within 10 minutes, is in keeping with Sircus's findings in the $\operatorname{dog}(1958)$. Failure of the acid secretion to return to normal rates in most of our patients, within the time of the test, again confirms other work (Sircus, 1958; Long, Brooks, and Sandweiss, 1963) where an inhibitory period of between 90 and 120 minutes is recorded. Long et al (1963) noted that the acid output after food was delayed by the period of reduced secretion induced by fat, reaching the expected output by the end of a six-hour period. This could be due to a reduction in stomach motility after fat has been introduced into the duodenum, delaying gastrin release from the antrum. A similar effect on motility has been described by Card (1941) in man. This is unlikely to be the cause of acid inhibition in our experiment since exogenous pentagastrin provided the secretory stimulus and is independent of antral function.

The reduction of pepsin concentration in the gastric juice seen after the infusion of fat is similar to that demonstrated in the vagally innervated dog stomach (Grossman, Greengard, Woolley, and Ivy, 1944). Schofield (1959) demonstrated reduction of pepsin output coincident with lessening of motility and thought this to be due to a humoral agent.

To determine whether denervation influenced the inhibition observed in our experiment, three patients were studied after vagotomy and pyloroplasty. One patient (Table IV) responded following a complete vagotomy. The other two showed reduced secretion but bile reflux was a major problem and the results were not considered significant. We believe there are no indications that the phenomenon of inhibition in man is any different from that observed in dogs (Halvorson, Middleton, Bibler, Harkins, and Nyhus, 1966), that it is probably due to the release of a 
humoral agent from the intestine, and is not dependent on an intact nerve supply. The cross transfusion studies of Johnston and Duthie (1966) suggest that duodenal acidification in man also releases an inhibitory hormone.

Results in the group of duodenal ulcer patients (Table II) show that in them the inhibitory capacity was not reduced. In fact, the mean decrease in acid output of this group was greater than in our controls. All duodenal ulcer cases had high rates of secretion and a correlation between maximal acid output and degree of inhibition was sought but not established.

Inhibition of gastric secretion by fat in the small intestine is dependent upon fat absorption (Menguy, 1959 and 1960; Konturek and Grossman, 1965). Diseases in which fat absorption is impaired either due to maldigestion or malabsorption might be expected to show an abnormal response. It was with this hypothesis in mind that we investigated patients with steatorrhoea. Our results so far are not conclusive but the patient with the most severe mucosal lesion (no. 19) failed to show inhibition, and the one with no terminal ileal function and gross steatorrhoea (no. 18) showed only a slight response.

The increased hydrogen ion concentration of the gastric juice seen in some patients when inhibition was induced (Fig. 5) is a finding which suggests a selective effect on sodium or potassium in the gastric juice. This aspect of gastric secretion has been well studied in relation to insulin by Hirschowitz (1966). He demonstrated a reduction of potassium ion concentration in the gastric juice when insulin was given in high dosage to inhibit the acid output. We wondered if there was a similar change following fat inhibition, but have been unable to demonstrate consistent changes in the electrolyte content of the juice.

An inhibitory agent released from the duodenum on contact with fat was known to Pavlov (1910) but it was not until 1930 that Kosaka and Lim named it, enterogastrone. The substance, extracted from duodenal and small intestinal mucosa, was shown to inhibit both acid secretion and motility. Later work has confirmed these properties (Greengard, Atkinson, Grossman, and Ivy, 1946; Gregory and Tracey, 1959; Kaulbersz, Patterson, and Sandweiss, 1962) and shown a reduction in juice stimulated by food and insulin. Gregory (1956) was unable to demonstrate clearly a diminution of histamine-stimulated juice by instilling fat into the duodenum, but later (1959) he found inhibition of acid produced by antral stimulation.

Treatment of ulcer patients with enterogastrone was suggested and tried by Ivy in 1944. Forty-three patients were treated with equivocal results. Other workers (Bone, Cassel, Ruffin, and Reeves, 1951;
Wollum and Pollard, 1951) found enterogastrone of little value in ulcer therapy. Grossman (1950) reviewed the literature on enterogastrone and indicated that it had never been isolated in pure form nor was its structure known. It is difficult to assess the significance of enterogastrone as a gastric inhibitory hormone and some would doubt its existence.

An alternative hypothesis is that the inhibitory agents are bile salts or products of fat absorption and that no separate hormone exists.

Still and Carlson (1929) found that intravenous injection of bile into dogs reduced stomach motility and diminished gastric secretion. More recently, Menguy and Peissner (1960) reported inhibition by bile salts of fasting and histamine-stimulated juice as well as a direct effect on the parietal cell of an isolated mucosal preparation. The most effective of the salts in these experiments was sodium desoxycholate. However, sodium cholate, glycocholate, and taurocholate were all highly active. Following biliary diversion to the colon or bile duct ligation, Menguy (1962) noticed hypersecretion from dogs, the increase being in the region of $300 \%$.

Drasar, Hill, and Shiner (1966) have shown that bile salts can be deconjugated by intestinal bacteria, such as Bacteroides (fusiformis) found in the gut of patients with the blind loop syndrome. Landor, Baker, and Hite (1963) demonstrated gastric hypersecretion in dogs after the construction of blind loops of small intestine, but were unable to influence this with antibiotics. It may well be that bile salts are removed from their effective site by such a mechanism as deconjugation. Nicoloff (1966) has demonstrated in dogs that bile salt adsorption by cholestyramine leads to increased acid output. From this evidence it seems possible that bile salts themselves may be inhibitors of gastric secretion in normal animals. Their role in controlling secretion in man has not been evaluated.

The effect on gastric secretion of fat introduced into the gut lumen has been studied fully in animals but little information exists on the effect of fats administered into the blood stream. Lim (1929) injected chyle intravenously and found no effect on gastric secretion. Fractionation of thoracic duct lymph has produced both an inhibitory substance (Rudick, Gajewski, Semb, Pitts, Fletcher, Harkins, and Nyhus, 1965) and a secretagogue (Kelly, Ikard, Nyhus, and Harkins (1963). The work of Baume, Meng, and Law (1966) introduced a new concept into this field when they reported that Intralipid (Vitrum) decreased the fasting acid secretion from pylorus-ligated rats. Infusion of Intralipid (Vitrum) intravenously during continuous pentagastrin stimulation in dogs with a Heidenhain pouch has given 
equivocal results in experiments carried out by one of us (C.W.O.W.).

The role of fats by themselves as inhibitory agents is unclear and uncertain, but their normal absorption seems necessary for normal gastric function. Menguy (1960) found bile, lipase, and fat the most effective mixture when introduced into the small intestine to inhibit secretion from fasting rats' stomachs. Bile and fat were less effective and bile salts alone least of all. Konturek and Grossman (1965) showed that inhibition of gastrin-stimulated juice by bile salts and fat was greatest after introduction into the jejunum, where fat is most rapidly absorbed.

The question as to whether inhibition of gastric secretion is due to release of a hormone, enterogastrone, or to absorption of bile or fats themselves cannot be answered in our present state of knowledge. Further studies on the effect of fat malabsorption and biliary disorders on gastric secretion in man would be helpful.

Our results show that the fat-induced inhibitory mechanism present in the duodenum and upper jejunum of man is not impaired in patients with duodenal ulceration.

\section{SUMMARY}

A simple method is described for assessing the inhibitory capacity of the duodenum and small intestine in man.

An emulsion of ground nut oil was infused into the small intestine whilst gastric secretion induced by a continuous pentagastrin infusion was measured. A consistent and immediate reduction of acid and pepsin secretion persisted in most cases for at least 40 minutes.

The mean reduction in output of acid in a control group of eight was $59 \%$, in duodenal ulcer $70 \%$, and in a group with miscellaneous small bowel disorders, $50 \%$. There would seem to be no reduction of the inhibitory capacity in duodenal ulcer with respect to fat.

Comparison of the characteristics of the inhibition in man with that reported in animals shows it to be similar in all respects. The agent responsible is probably humoral, and would seem to act at parietal cell level since inhibition was evident even during a continuous infusion of pentagastrin.

Current views on enterogastrone and other possible humoral factors are discussed.

This work was supported by a grant from the Endowment Fund of the United Birmingham Hospitals. Acknowledgments are made to Dr J. D. Fitzgerald, M.R.C.P., of Imperial Chemical Industries Ltd., for supplying pentagastrin for this trial and to Mr J. Alexander Williams, Ch.M., F.R.C.S., consultant surgeon at the General
Hospital, Birmingham, for advice and help in preparing this paper. Radiological facilities were made available by Dr O. E. Smith, and we would like to thank Dr R. W. N. Davis, for his assistance in this work.

\section{REFERENCES}

Andersson, S. (1960). Inhibitory effects of hydrochloric acid in the duodenum on gastrin-stimulated gastric secretion in Heidenhain pouch dogs. Acta physiol. scand., 50, 105-112.

Anson, M. L. (1938). The estimation of pepsin, trypsin, papain, and cathepsin with hemoglobin. J. gen. Physiol. 22, 79-89.

Baume, P. E., Meng, H. C., and Law, D. H. (1966). Intravenous fat emulsion and gastric secretion in the rat. Amer. J. dig. Dis., 11, $1-9$.

Bibler, D. D., Jr, Harkins, H. N., and Nyhus, L. M. (1965). Inhibition of exogenous gastrin-stimulated gastric secretion by fat in the duodenum. Rev. Surg. (Philad.), 22, 455-456.

Bone, F. C., Cassel, C., Ruffin, J. M., and Reeves, R. J. (1951). Enterogastrone parenterally in the treatment of peptic ulcer; a controlled clinical study. Gastroenterology, 17, 35-38.

Card, W. I. (1941). A comparison of the inhibitory action of different fats and fatty acids introduced into the duodenum on gastric contractions. Amer. J. dig. Dis., 8, 47-53.

Drasar, B. S., Hill, M. J., and Shiner, M. (1966). The deconjugation of bile salts by human intestinal bacteria. Lancet, 1, 1237-1238.

Ewald, C. A., and Boas, J. (1886). Beiträge zur Physiologie und Pathologie der Verdauung. II. Virchows Arch. path. Anat., 104, 271-305.

Feng, T. P., Hou, H. C., and Lim, R. K.. S. (1929). Mechanism of inhibition of gastric secretion by fat. Chin. J. Physiol., 3, 371-380.

Greengard, H., Atkinson, A. J., Grossman, M. I., and Ivy, A. C. (1946). The effectiveness of parenterally administered 'enterogastrone' in the prophylaxis of recurrences of experimental and clinical peptic ulcers with a summary of 58 cases. Gastroenterology, 1, 625-649.

Gregory, R. A. (1956). Motor and secretory inhibition of duodenal origin in transplanted gastric pouches. J. Physiol. (Lond.), 132, 67P-68P.

- , and Tracy, H. J. (1959). The action of enterogastrone on gastric secretion. Ibid., 149, 58P-59P.

Grossman, M. I., Greengard, H., Woolley, J. R., and Ivy, A. C. (1944). Pepsin secretion and enterogastrone. Amer. J. Physiol., 141, 281-288.

Grossman, M. I. (1950). Gastrointestinal hormones. Physiol. Rev., 30,33-90.

Halvorson, H. C., Middleton, M. D., Bibler, D. D., Jr., Harkins, H. N., and Nyhus, L. M. (1966). Influence of the vagus nerve on the inhibitory effect of fat in the duodenum. Amer. J. dig. Dis., 11, 911-917.

Hirschowitz, B. I. (1966). Quantitation of inhibition of gastric electrolyte secretion by insulin in the dog. Ibid., 11, 173-182.

(1966). Characteristics of inhibition of gastric electrolyte secretion by insulin. Ibid., 11, 183-198.

-_, and Robbins, R. C. (1966). Direct inhibition of gastric electrolyte secretion by insulin, independent of hypoglycemia or the vagus. Ibid., 11, 199-212.

, and Sachs, G. (1966). Reversal of insulin inhibition of gastric secretion by intravenous injection of potassium. Ibid., 11, 217-230.

Hofmann, A. F. (1967). The syndrome of ileal disease and the broken enterohepatic circulation: cholerheic enteropathy. Gastroenterology, 52, 752-757.

Hunt, J. N. (1957). Influence of hydrochloric acid on gastric secretion and emptying in patients with duodenal ulcer. Brit. med.J., 1, 681-684.

Ivy, A. C. (1944). The prevention of recurrence of 'peptic' ulcer: an experimental study. Ibid., 3, 443-449.

Johnston, D., and Duthie, H. L. (1964). Effect of acid in the duodenum on histamine-stimulated gastric secretion in man. Gut, 5, 573-580.

_- - (1965). Inhibition of gastrin secretion in the human stomach. Lancet, 2, 1032-1036.

- - - (1966). Inhibition of histamine-stimulated gastric secretion by acid in the duodenum in man. Gut, 7, 58-68.

Kaulbersz, J., Patterson, T. L., and Sandweiss, D. J. (1962). Effect on gastric secretion of enterogastrone prepared from normal and from hypophysectomized dogs. Gastroenterology, 42, 169-170. 
Kelly, K. A., Ikard, R. W., Nyhus, L. M., and Harkins, H. N. (1963). Gastric secretogogues in postprandial thoracic duct lymph. Amer. J. Physiol., 205, 85-88.

Konturek, S., and Grossman, M. I. (1965). Effect of perfusion of intestinal loops with acid, fat, or dextrose on gastric secretion. Gastroenterology, 49, 481-489.

Kosaka, T., and Lim, R. K. S. (1930). Demonstration of the humoral agent in fat inhibition of gastric secretion. Proc. Soc. exp. Biol. (N.Y.), 27, 890-891.

Lancet (1967). The effect of vagotomy on gastric secretion elicited by pentagastrin in man. A Multicentre Study, Lancet, 2, 534-536.

Landor, J. H., Baker, W. K., and Hite, D. F. (1963). Blind intestinal loops in dogs: effect on Heidenhain pouch secretion. Arch. Surg., 87, 1048-1052.

Lim, R. K. S., Ivy, A. C., and McCarthy, J. E. (1925). Contributions to the physiology of gastric secretion. 1. Gastric secretion by local (mechanical and chemical) stimulation. Quart. J. exp. Physiol., 15, 13-68.

Long, J. F., Brooks, F. P., and Sandweiss, D. J. (1963). A comparison of fats of varying saturation as inhibitors of canine gastric secretion. Gastroenterology, 45, 638-643.

Menguy, R. (1959). Mechanism of inhibition of gastric secretion by fat in the intestine. Proc. Soc. exp. Biol. (N.Y.), 102, 274-276.

- (1960). Studies on the role of pancreatic and biliary secretions in the mechanism of gastric inhibition by fat. Surgery, 48, 195-200.

-, and Peissner, L. (1960). In vivo and in vitro effects of bile salt compounds on gastric secretory activity. Amer. J. dig. Dis., $5,669-676$.

Menguy, R. B. (1962). Mechanism of gastric hypersecretion in dogs with exclusion of bile or pancreatic juice from the small intestine. Surg. Forum, 13, 300-302.

Pavlov, I. P. (1910). The Work of the Digestive Glands, 2nd Engl. ed., p. 120. Griffin, London.
Roberts, W. M. (1931). The effect of oils on gastric secretion and motility. Quart. J. Med., 24, 133-152.

Rudick, J., Gajewski, A. K., Semb, L. S., Pitts, C. L., Fletcher, T. L., Harkins, H. N., and Nyhus, L. M. (1965). Isolation of a gastric inhibitor substance in thoracic duct lymph. Surg. Forum, 16, 317-319.

Schofield, B. (1959). The inhibition of pepsin output in separated gastric pouches in dogs following feeding, and its correlation with motility changes. Gastroenterology, 37, 169-181.

Shay, H., Gershon-Cohen, J., and Fels, S. S. (1939). The role of the upper small intestine in the control of gastric secretion; the effect of neutral fat, fatty acid, and soaps; the phase of gastric secretion influenced and the relative importance of the psychic and chemical phases. Ann. intern. Med., 13, 294-307.

_,-1 - (1942). A self-regulatory duodenal mechanism for gastric acid control and an explanation for the pathologic gastric physiology in uncomplicated duodenal ulcer. Amer. J. dig. Dis., 9, 124-128.

Sircus, W. (1958). Studies on the mechanisms in the duodenum inhibiting gastric secretion. Quart. J. exp. Physiol., 43, 114-133.

Still, K. S., and Carlson, A. J. (1929). The motor and secretory activity of the stomach during acute and chronic obstructive jaundice in dogs. Amer. J. Physiol, 89, 34-45.

Thompson, J. C. (1962). The inhibition of gastric secretion by the duodenum and by the gastric antrum: a review. J. surg. Res., 2, 181-196.

Wollum, A., and Pollard, H. M. (1951). The ineffectiveness of enterogastrone on severe chronic peptic ulcer in man. Gastroenterology, 17, 535-540.

Woodward, E. R., and Schapiro, H. (1958). Duodenal inhibitor mechanism in duodenal ulcer patients. J. appl. Physiol., 12, 55-56. 